\title{
Linking ecosystem services with landscape history
}

\author{
Matthias Bürgi • Janet Silbernagel • \\ Jianguo Wu $\cdot$ Felix Kienast
}

Received: 2 June 2014/Accepted: 7 October 2014/Published online: 17 October 2014

(C) The Author(s) 2014. This article is published with open access at Springerlink.com

\begin{abstract}
The concept of ecosystem services (ES) has become widely used because it bridges ecology and economics and links nature to society. ES may evolve over time in dynamic landscapes driven by myriad processes. However, the consequences of changes in key ES has not been considered adequately in current ES research. Here we propose a framework for linking ES with landscape history, which can help us better understand the evolution of ES over time. We illustrate the framework by a case study from Switzerland. Both the capacity of landscapes to supply ES and the realization and recognition of key ES are likely to change over time. This insight should have important implications for landscape sustainability and related scenario studies.
\end{abstract}

M. Bürgi $(\varangle) \cdot$ F. Kienast

WSL Swiss Federal Institute for Forest Snow and Landscape Research, Zürcherstrasse 111,

8903 Birmensdorf, Switzerland

e-mail: matthias.buergi@wsl.ch

J. Silbernagel

Nelson Institute for Environmental Studies, University of Wisconsin, Madison, WI, USA

J. $\mathrm{Wu}$

School of Life Sciences \& Global Institute of Sustainability, Arizona State University, Tempe, AZ, USA
Keywords Ecosystem services · Landscape history · Land use and land cover - Driving forces . Landscape sustainability $\cdot$ Scenarios $\cdot$ Switzerland

\section{Introduction}

The concept of ecosystem services dates back to the mid-1960s, with references to ecosystem functions, services and their economic value (de Groot et al. 2002), leading to the proposition of an utilitarian approach of ecosystem services of biodiversity in the late 1970s (Gómez-Baggethun et al. 2010). Since the late 1990s, the concept has gained increasing attention in academic, management, and policy arenas. The connection from science to policy has been bolstered strongly by the United Nations Millennium Ecosystem Assessment (Millennium Ecosystem Assessment 2005), which centred on the concept of ecosystem services in relation to human well-being (see also $\mathrm{Wu}$ 2013). To recognize the diversity of goods and services, the Millennium Ecosystem Assessment (2005) distinguished between provisioning, regulating, supporting and cultural ES. Given the complexity of the real world, any classification of ES has limitations (e.g. Wallace 2007), and the ES concept has faced various partly contrasting criticisms (Schröter et al. 2014). This did not, however, hinder the spread of the concept into management and policy because the concept helps address several core 
difficulties that these fields face, ranging from monitoring and valuing ecosystem processes and assets of a country or a region (Wallace 2007) to assessing the diversity of environmental effects of a policy or a project. Exploring future effects of zoning regulations (Geneletti 2013), conservation strategies (Price et al. 2012) and climate change (Forsius et al. 2013) on ES is now an important topic in ES research, which can have implications for adaptation and mitigation strategies relevant to policy making.

However, much of the ES research so far has not considered the temporal dynamics of landscapes explicitly. In addition to obvious seasonal changes, ES certainly undergo long-term dynamics due to landscape history as (a) ecosystem properties (structures and processes) change, be they natural processes or human-induced (e.g. succession or land use), and (b) demands for ES also change because of factors such as population dynamics, technological innovations, and socioeconomic changes.

These long-term dynamics of ES are quite relevant and important also to estimating future ES. Studies assessing future ES are most commonly based on a set of ES that is currently considered important by the stakeholders or the researchers. We do not know, however, if this set of ES will remain the same in the future. Several factors may contribute to long-term changes in ES, including scientific insights that bring new ecosystem services to light and emerging concerns, such as climate change, which shift more emphasis to certain specific and novel services, to name just a few.

It is formidable to predict what ES will be recognized as important by the public in just a few decades or more. But we can analyze how stable realized ES have been over time by looking back. Linking the ES concept with landscape history provides valuable insights into the dynamics of ES (Iverson et al. 2014), which is necessary for adequate planning and the validity of scenario modeling. The best proxies to infer on former ES provision (both realized and potential) are (1) current land-use/land cover and (2) its change over time (Lautenbach et al. 2011), although the relationship may be nonlinear (Grêt-Regamey et al. 2014). We know that simple extrapolations from the past into the future are unwarranted, but such a retrospective approach can help us gain insights on how ES evolve over time. Landscape ecology, with its long history of generating such spatiotemporal datasets, is poised to deliver these proxies. The importance of such a historical approach has been demonstrated in several studies from North America (Hammett 1992; Silbernagel et al. 1997), South America (Arce-Nazario Javier 2007), North Europe (Olsson et al. 2000), Central Europe (Bender et al. 2005; Bürgi et al. 2010), Asia (Long et al. 2007), and Australia (Bohnet and Pert 2010).

Many of these studies, however, do not explicitly link land use change to ES provision, and only a few studies are available which assess ES provision over historical times. Whereas some studies focus on changes in the last decades (e.g. Lautenbach et al. 2011; Nahuelhual et al. 2014), there are also examples that cover longer time spans. For example, a largescale study of Carreño et al. (2012) analyzed 50 years of ecosystem service trade-offs in Argentina; a smallscale study for both Stockholm and Melbourne had a time frame of roughly 80 years (Wilkinson et al. 2013); Morán-Ordóñez et al. (2013) studied changes in ES provided by heathlands in northwestern Spain since the 1950s; and Jiang et al. (2013) examined 70 years of ES changes in relation to biodiversity in southern England. However, all these studies start with the currently important ES and evaluate how they changed over time. We are not aware of any study exploring if and how the set of important ES itself changed over time.

Considering the temporal dynamics of ES brings up various questions, such as: Were there any recreational values at a time society did not have time for recreational activities? Is mass stabilisation and control of erosion rates a regulating service when erosion is not recognized as a problem? While pollination may be called an ES even if society is unaware of its relevance, are there still regulating services unknown to us due to limited scientific knowledge? Towards addressing these questions, we first propose a conceptual framework depicting the various dimensions of ES, and then illustrate historical changes in recognized ES through an example from Swiss alpine pasture landscapes. In addition, we explore some preliminary implications for scenario-building and landscape sustainability.

Framework linking ES with landscape history

To facilitate the integration of historical development into studies of ES, we propose to analyze ES in a 


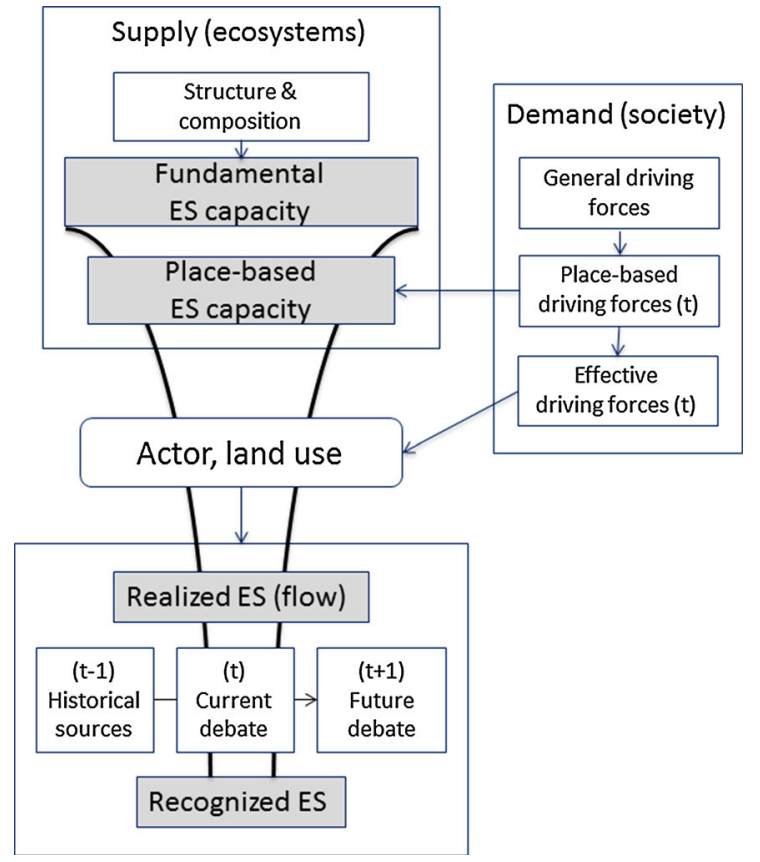

Fig. 1 Studies considering the historical dimension of ES profit from distinguishing four nested levels of ES. In a specific location and for a specific time, only a sub-set of the general ES capacity is available, depending on the place-based driving forces. Land users realize a few ES, out of this reduced set of ES

hierarchical structure, distinguishing four nested levels (Fig. 1):

- Fundamental ES: those services that are of fundamental validity, regardless of state of science, public awareness and demand.

- Place-based ES: those services that are available only in a specific place and during a certain period of time.

- Realized ES: those services that are actually consumed or utilized in some way in a specific landscape.

- Recognized ES: those services that the actors on the land as well as society at large are aware of realizing (i.e., consuming and using) in a specific place and time.

The fundamental ES capacity is based on the structure and composition of ecosystems and landscapes in general and the processes and cycles based on them (e.g. Kienast et al. 2009). Several terms have been used for the capacity of providing ecosystem services, such as "supply" (Schröter et al. 2005; Burkhard et al. 2012; Jones et al. 2013), "stock and capacity" (Kienast et al. 2009; Bateman et al. 2011; Layke et al. 2012; Helfenstein and Kienast 2014), and “potential” ES capacity (Koschke et al. 2012). We recognize that the stock-flow paradigm-also referred to as the cascade model (Haines-Young and Potschin 2009) — has some shortcomings (see Norgaard 2010), but in the absence of a widely tested alternative we consider that it remains a useful conceptual construct at hand.

We propose to distinguish between the place-based ES capacity, which is theoretically available for a given time and a given place, and the realized ES. The relevant context for the place-based ES depends on the demand modified by the political/legal, socio-economic, cultural and technological context, i.e. the place-based driving forces such as legal restrictions and available technology (Bürgi et al. 2004). These driving forces change over time (Fig. 1). Only a subset of the place-based ES are actually realized by the actors in a specific land use, depending on the effective driving forces. Which ones of the place-based driving forces are actually effective on the ground depends largely on the land users (i.e., the actors): not all technologies available are applied, and not all legal restrictions are always followed. The personal situation of the land users, including education and access to information, age (e.g., time until retirement) and succession plan, financial situation, access to subsidies, potential for alternative (e.g., off-farm) income and other economic factors, all play an important role in the decision to realize a specific ES. This decision might induce a specific land-use. However, because the same ES can be generated with different land-uses, and because one land-use can result in various ES, the decision to realize a specific ES is rarely the only driver for a specific land-use. The specific land use has feedback effects on the processes, cycles and regulations of ecosystems and landscapes, thus contributing to their changes over time.

While regulating ES operate independently of being recognized by humans, provisioning and especially cultural services need a specific demand to exist. Apart from demand, the level of (scientific or traditional) knowledge of and insights in underlying ecological processes also determines what society can perceive as ES out of the list of realized ES. We call this sub-set of ES "recognized" ES. The recognized ES and the driving forces are interlinked, as only recognized ES can trigger innovations, lead to debates 
on wanted adaption of legal frameworks or put pressure on policy making. This dynamic will determine, to a large extent, what set of recognized ES will be relevant in the future and, consequently, in what form of land use this set of ES will be realized.

Although the set of future ES recognized by society is difficult to assess, it is possible to figure out the historical changes of recognized ES in an area by taking a retrospective approach. Historical studies are often limited by data availability, and when data are available, their accuracy may be influenced by the authors' subjectivity (Forman and Russell 1983). In the following, we illustrate long-term changes in ES through a case study in Swiss alpine pasture landscapes, where we have comparable repeated surveys over 100 years. The key question in this study was: What ES have been considered important at different times in the past?

\section{Evolution of ES provided by Swiss alpine pasture landscapes since 1900}

Data and analysis

Mountain regions characteristically provide very diverse ES (Grêt-Regamey et al. 2012), such as protection from natural hazards, water supply, scenic beauty for tourism etc. A series of encompassing and systematic assessments of mountain pastures in Switzerland conducted over the last century enables us to study long-term changes in recognized ES mentioned in published reports. The first cadaster on alpine pastures was initiated and conducted by the "Schweizerische alpwirtschaftliche Verein", a private organization founded in 1863 aiming at modernizing the state of alpine agriculture. A series of about 20 cantonal monographs published between 1894 and 1911 was summarized in a monograph "Die Alp- und Weidewirtschaft in der Schweiz" published in 1914 (Strüby 1914). The book therefore gives a systematic overview on the situation of alpine pasture farming in Switzerland at around 1900. The second cadaster was again based on cantonal studies, which were published between 1954 and 1982 and again summarized in a final monograph with exactly the same title as the first cadaster (Werthemann and Imboden 1982). The present state of alpine pasture farming in Switzerland is assessed in an encompassing interdisciplinary study called AlpFutur (www.alpfutur.ch), the results of which are summarized in a final report (Lauber et al. 2013), which can be interpreted as a third cadaster, as it provides an overview on the state of alpine pasture farming in Switzerland at around 2010.

The analysis of written sources is based on a sourcecritical approach, as commonly used in historical sciences (Forman and Russell 1983). It includes the careful assessment of the function and intention of the documents evaluated. As outlined, the three monographs used as main sources were very similar in their aim and character. Therefore, they can be used in a comparative way to study changes in recognized ES over time. To conduct this comparison, the text of the monographs were coded according to a classification scheme of ES, based on the CICES scheme (Version 4.3) to the class level (CICES $=$ Common International Classification of Ecosystem Services, www. cices.eu). The CICES scheme V4.3 distinguishes 20 groups of ES and further splits them into 48 classes. Some of the class labels were reworded slightly to better represent the specific situation in the study area. Statements from the text which referred to ES, were assigned to the respective class. The aim was not to count the number of times a certain ES was mentioned, but to assess which ES were considered to be important at a certain period. We therefore classified quotes as $\mathrm{A}=\mathrm{ES}$ mentioned as important, $\mathrm{B}=\mathrm{ES}$ mentioned, $\mathrm{C}=$ anecdotal reference to $\mathrm{ES}, 0=\mathrm{ES}$ not mentioned. Additionally, we included the classes $\mathrm{N}=\mathrm{ES}$ not mentioned, but performed, $\mathrm{NN}=\mathrm{ES}$ not mentioned, but present. With $\mathrm{N}$ we classified $\mathrm{ES}$ which were mentioned for at least one period, but not mentioned at all in the others, despite that we know from other sources or own expertise, the ES still was used. NN encompasses ES which were either well known to be present and probably mentioned at least in one period, but general knowledge tells us that the ES were present continuously.

\section{Historical changes in ES}

Out of the 48 classes of ES listed in CICES, 23 ES were mentioned in the sources evaluated, out of which thirteen belong to the section "Provisioning", five to "Regulation and Maintenance" and the remaining five to "Cultural" (Table 1). Whereas nine ES were classified continuously as A or B for all three time steps, three are either new or show an increase in the 
Table 1 In Swiss alpine pasture landscapes, different sets of ES are realized in 1900, 1970 and 2010

\begin{tabular}{|c|c|c|c|c|c|c|}
\hline Section & Division & Group & Specific & 1900 & 1970 & 2010 \\
\hline \multicolumn{7}{|l|}{$\mathrm{A}, \mathrm{B}$-continuity } \\
\hline \multirow[t]{5}{*}{ Provisioning } & Nutrition & Biomass & $\begin{array}{l}\text { Milk, cheese, butter, } \\
\text { meat }\end{array}$ & A & A & A \\
\hline & & Water & Drinking water & B & B & B \\
\hline & Materials & Water & $\begin{array}{l}\text { Water for livestock, } \\
\text { irrigation }\end{array}$ & A & A & A \\
\hline & & Biomass & Timber & $\mathrm{B}$ & B & $\mathrm{B}$ \\
\hline & Energy & Biomass-based energy sources & Fire wood & $\mathrm{B}$ & $\mathrm{B}$ & $\mathrm{B}$ \\
\hline $\begin{array}{l}\text { Regulation \& } \\
\text { Maintenance }\end{array}$ & Mediation of flows & Mass flows & $\begin{array}{l}\text { Erosion control, } \\
\text { avalanche } \\
\text { protection }\end{array}$ & A & A & A \\
\hline \multirow[t]{2}{*}{ Cultural } & $\begin{array}{l}\text { Physical and intellectual } \\
\text { interactions }\end{array}$ & $\begin{array}{l}\text { Intellectual and representative } \\
\text { interactions }\end{array}$ & Cultural heritage & A & A & A \\
\hline & & & Aesthetics & $\mathrm{B}$ & $\mathrm{B}$ & $\mathrm{B}$ \\
\hline \multicolumn{7}{|c|}{$\mathrm{A}, \mathrm{B}-\mathrm{new}$, increase } \\
\hline Provisioning & Energy & $\begin{array}{l}\text { Renewable abiotic energy } \\
\text { sources }\end{array}$ & Hydropower & 0 & A & A \\
\hline \multirow[t]{2}{*}{ Cultural } & $\begin{array}{l}\text { Physical and intellectual } \\
\text { interactions }\end{array}$ & $\begin{array}{l}\text { Physical and experiential } \\
\text { interactions }\end{array}$ & Tourism & $\mathrm{B}$ & B & A \\
\hline & & $\begin{array}{l}\text { Intellectual and representative } \\
\text { interactions }\end{array}$ & Education & 0 & $\mathrm{~B}$ & A \\
\hline \multicolumn{7}{|c|}{ A, B-decrease, abandoned } \\
\hline \multirow[t]{4}{*}{ Provisioning } & Materials & Biomass & Hay & A & B & $\mathrm{B}$ \\
\hline & & & Litter & A & 0 & 0 \\
\hline & Energy & Biomass-based energy sources & $\begin{array}{l}\text { Peat (only party } \\
\text { renewable) }\end{array}$ & $\mathrm{B}$ & 0 & 0 \\
\hline & & & Dung & $\mathrm{C}$ & 0 & 0 \\
\hline \multicolumn{7}{|l|}{$\begin{array}{l}\text { Unmentioned, } \\
\text { but performed }\end{array}$} \\
\hline \multirow[t]{3}{*}{ Provisioning } & Nutrition & Biomass & Food for personnell & B & $\mathrm{N}$ & $\mathrm{N}$ \\
\hline & & & Wild plants collected & $\mathrm{B}$ & $\mathrm{N}$ & $\mathrm{N}$ \\
\hline & & & Game & $\mathrm{C}$ & $\mathrm{N}$ & $\mathrm{N}$ \\
\hline Cultural & $\begin{array}{l}\text { Physical and intellectual } \\
\text { interactions }\end{array}$ & $\begin{array}{l}\text { Intellectual and representative } \\
\text { interactions }\end{array}$ & Research & $\mathrm{B}$ & $\mathrm{B}$ & $\mathrm{B}$ \\
\hline \multicolumn{7}{|l|}{$\begin{array}{l}\text { Unmentioned, } \\
\text { but present }\end{array}$} \\
\hline \multirow{4}{*}{$\begin{array}{l}\text { Regulation \& } \\
\text { maintenance }\end{array}$} & Mediation of flows & Liquid flows & Water regulation & $\mathrm{NN}$ & A & A \\
\hline & $\begin{array}{l}\text { Maintenance of physical, } \\
\text { chemical, biological } \\
\text { conditions }\end{array}$ & $\begin{array}{l}\text { Lifecycle maintenance, habitat } \\
\text { and gene pool protection }\end{array}$ & Pollination & $\mathrm{NN}$ & NN & NN \\
\hline & & & Biodiversity & $\mathrm{NN}$ & $\mathrm{NN}$ & A \\
\hline & & $\begin{array}{l}\text { Atmospheric composition and } \\
\text { climate regulation }\end{array}$ & $\begin{array}{l}\text { Carbon sequestration, } \\
\text { climate regulation }\end{array}$ & $\mathrm{NN}$ & NN & A \\
\hline
\end{tabular}

$\mathrm{A}=\mathrm{ES}$ mentioned as important, $\mathrm{B}=\mathrm{ES}$ mentioned, $\mathrm{C}=$ anecdotal reference to $\mathrm{ES}, 0=\mathrm{ES}$ not mentioned, $\mathrm{N}=\mathrm{ES}$ not mentioned, but performed, NN = ES not mentioned, but present. Sources used are given in the text 
study period (i.e. hydropower, tourism, and education). Four ES, all belonging to "Provisioning", were either abandoned or reduced in importance (i.e., the collection and use of hay, litter, peat and dung).

We see persistency in core provisioning services such as the classic products from alpine pasture farming (i.e., milk, cheese, butter, and meat) and the services needed to produce them (i.e., fodder such as grass and water for livestock and erosion control for the pasture area itself).

All ES classified as either $\mathrm{N}$ or $\mathrm{NN}$ in at least one period were analyzed separately. The N-class contains three "Provisioning" ES (Food for personnel working on the alpine pastures, collection of wild plants, and game for hunting), which were only mentioned for 1900, but not for 1970 or 2010. The NN-class encompasses four ES all belonging into the section "Regulation \& Maintenance", three out of which were mentioned just in for 2010 (Water flow mediation, Biodiversity, Carbon sequestration/climate regulation) and Pollination, which was not mentioned in any of the reports at all, but for sure was an important ES throughout the study period.

Comparing how the different sections developed over time (Table 2), we found that provisioning ES were the largest group of recognized ES throughout the study period and that only few of them were abandoned (litter, peat, and dung). This seems to correspond with Maslow's hierarchy of human needs in which provisioning services are placed at the very bottom, a conceptual framework considered quite relevant to understanding human well-being ( $\mathrm{Wu}$ 2013). Regulation and Maintenance gained in recognition throughout the study period, as some ES belonging into this section were not recognized in 1900, despite they certainly were present. Cultural services also gained in importance over time, as more such ES were classified as A for 2010.

How can we gain insights into the dynamics of recognized ES from this historical example? The main new ES mentioned in the sources are Hydropower and Education (apart from the regulating ES, which we consider to be present, even if not mentioned). Hydropower, as a new ES representing the growing demand for energy, is a core characteristic of modern society and accentuated for Switzerland since World War II (Pfister 1994). Educational activities, together with recreation, illustrate the needs of an increasingly urban population, which strives to visit alpine
Table 2 The set of realized ES changes over time. ES related to regulation and maintenance, as well as cultural ES gain in importance in the course of the 20th century

\begin{tabular}{|c|c|c|c|c|c|c|c|}
\hline & A & B & $\mathrm{C}$ & 0 & $\mathrm{~N}$ & NN & Total \\
\hline \multicolumn{8}{|c|}{ Provisioning } \\
\hline 1900 & 4 & 6 & 2 & 1 & 0 & 0 & 13 \\
\hline 1970 & 3 & 4 & 0 & 3 & 3 & 0 & 13 \\
\hline 2010 & 3 & 4 & 0 & 3 & 3 & 0 & 13 \\
\hline \multicolumn{8}{|c|}{ Regulation \& maintenance } \\
\hline 1900 & 1 & 0 & 0 & 0 & 0 & 4 & 5 \\
\hline 1970 & 2 & 0 & 0 & 0 & 0 & 3 & 5 \\
\hline 2010 & 4 & 0 & 0 & 0 & 0 & 1 & 5 \\
\hline \multicolumn{8}{|c|}{ Cultural } \\
\hline 1900 & 1 & 3 & 0 & 1 & 0 & 0 & 5 \\
\hline 1970 & 1 & 4 & 0 & 0 & 0 & 0 & 5 \\
\hline 2010 & 3 & 2 & 0 & 0 & 0 & 0 & 5 \\
\hline
\end{tabular}

Classification see caption Table 1, sources used are given in the text

landscapes, triggering new possibilities for income in these regions, which are otherwise economically challenged. Our case study reveals how place-based driving forces and their temporal dynamics open up new opportunities as reflected in the place-based capacity (Fig. 1). The series of three consecutive reports on the state of alpine pasture landscapes over 100 years shows a remarkable turn-over of realized and recognized ES and demonstrates well the temporal dynamics of ES.

\section{Concluding remarks}

The proposed framework

We have argued that it is useful to distinguish among four different definitions of ES: fundamental, placebased, realized, and recognized ES. This structure reflects well the scale-dependent character of ES, i.e. the fact that not all ES are available everywhere and that the specific historical, political/legal, socio-economic, cultural, and technological contexts influence which ES are realized in a specific place and at a specific time (see also Fig. 6 in Wu 2013)—out of which not all have to be also recognized by society (Fig. 1).

Our general framework (Fig. 1) provides a guideline to evaluate historical changes in ES, leading to 
insights into how recognized ES develop over time. Our case study illustrates some interesting historical changes of realized and recognized ES. For example, the set of provisioning ES waxed and waned over time, whereas regulating and maintaining ES were always there even though society might not be aware of them. Biodiversity (for ES "Lifecycle maintenance, habitat and gene pool protection", see CICES) was not mentioned in the 1900 and 1970 reports, but became an important topic in the 2010 report. Regulating and maintaining ES only caught people's attention when they became threatened and scarce. This points to the importance of distinguishing between realized and recognized ES.

\section{Changes in ES over time}

As illustrated here, the temporal dynamics of ES pose a great challenge to accurately projecting ES into the future. Biodiversity and carbon storage are rather recent additions to the list of important ES, and new ES will certainly arise. Our analysis shows that cultural, regulating, and provisioning ES have their specific ways of being conveyed from fundamental to recognized ES, which can be explained by their different position in the hierarchy of human needs (see $\mathrm{Wu}$ 2013). Provisioning services address basic survival needs and will therefore remain highly relevant for society. However, how these basic physiological needs, and needs addressing safety and security, are fulfilled over time can change. We see, for example, in western societies, a growing demand for healthy, organically grown food, but also an increase in demand for processed food. Competition between biomass production for food and that for fiber and energy will most likely increase with the transition toward more renewable energy (Tilman et al. 2009). Regulating services also address basic needs in the hierarchy of human needs, but might undergo farreaching changes when the effects of climate change will force societies to adapt land use. Mismatch between human needs and regulating services will accentuate issues like food security or climate refugees. Cultural services are related to human needs, which are located on higher levels in the respective hierarchy. The developments in telecommunication, trade and transport, and information technology are loosening the bounding of human activities and services to a single place (Kienast et al. 2007). As a result of global homogenization, places may become increasingly similar, and capital and people may become more and more "placeless". At the same time, however, the increasing importance of virtual environments created by IT technology, may also encourage people to seek identification with unique, local places, especially as rising fuel costs limit longdistance travel (Thayer 2008).

\section{Scenario studies}

Many landscape scenario studies with advanced modeling tools now consider the ability for future landscapes to provide ES under different management strategies (Carpenter et al. 2006; Santelmann et al. 2006; Nassauer et al. 2007; Wilhere et al. 2007; Chen et al. 2013). For example, in modeling forest scenarios, Nixon et al. (2014) evaluated the effectiveness of different conservation strategies to meet target species needs, while also sustaining timber harvests (Price et al. 2012). The scenarios evaluate the premise that blending resource extraction, such as sustainable timber harvest, and biodiversity conservation should yield greater socio-economic benefits without significantly compromising the conservation of biodiversity or the sustainable provisioning of ecosystem services.

Instead of simply extrapolating the set of ES currently considered important into the future, more emphasis should be given to the fundamental ES capacity and their vulnerability. This finding echoes scenario thinking, which acknowledges that past trajectories of change, such as climate, may not accurately project future trends (Peterson et al. 2003; Mahmoud et al. 2009). Special attention should be given to the rise of regulating and maintaining ES, which have made it to the political or scientific agenda, and scientists should consider carefully if and how such ES may change in the future.

We can never precisely predict how ES will evolve in the future, but our understanding of the dynamics of ES over time can be improved from historical analyses, as illustrated here. This enables us to develop alternative storylines for scenarios, considering the range of ES available if the demand for local resources will again increase, or if a transition to a fossil fuelfree future will drastically change the societal priorities expressed in the set of recognized ES. Importantly, one should note how different scenario techniques take into account that the set of ES 
resulting from one land use depends on various additional factors, such as harvest management parameters. In other words, while a particular land use (like hardwood forest) may not change, the way in which a forest is harvested may impact its ability to provide certain ES (Nixon et al. 2014; Swearingen et al. in press). At the same time one ES can be provided by various different land use practices, e.g. water holding capacity in a managed forest or unmanaged wet meadow. Therefore, more specific information on land use (management intensity, techniques, etc.) and the resulting ES shall be considered.

The scenario techniques should also reflect that there are yet unknown fundamental ES (see Fig. 1) that may be realized in the future, and that research, technology or societal development may eventually convert some of the realized ES to recognized ES.

\section{Interdisciplinary dialogue}

On a more methodological level, we consider the proposed distinction between fundamental ES, placebased ES, realized ES and recognized ES to be valuable in the interdisciplinary dialogue with social scientists, conservation practitioners, land managers, and decision-makers, as it emphasizes the inherently human-centered character of the ES approach. Including such groups in the scenario-building process will further improve not only the quality, but also the acceptance and relevance of scenario-based studies of ES development (Silbernagel et al. 2011; Price et al. 2012).

Acknowledgments Data used in this study on Swiss alpine pasture landscapes has been collected in the project "ALPAST - Changes in diversity of Swiss alpine pasture farming since 1880 — a landscape historical assessment" funded by the Swiss National Science Foundation (Grant No. CR31I2_132484).

Open Access This article is distributed under the terms of the Creative Commons Attribution License which permits any use, distribution, and reproduction in any medium, provided the original author(s) and the source are credited.

\section{References}

Arce-Nazario Javier A (2007) Human landscapes have complex trajectories: reconstructing Peruvian Amazon landscape history from 1948 to 2005. Landsc Ecol 22:89-101
Bateman IJ, Mace GM, Fezzi C, Atkinson G, Turner K (2011) Economic analysis for ecosystem service assessments. Environ Resour Econ 48:177-218

Bender O, Boehmer HJ, Jens D, Schumacher KP (2005) Analysis of land-use change in a sector of Upper Franconia (Bavaria, Germany) since 1850 using land register records. Landsc Ecol 20:149-163

Bohnet Iris C, Pert Petina L (2010) Patterns, drivers and impacts of urban growth-A study from Cairns, Queensland, Australia from 1952 to 2031. Landsc Urban Plan 97:239-248

Bürgi M, Hersperger A, Schneeberger N (2004) Driving forces of landscape change-current and new directions. Landsc Ecol 19:857-868

Bürgi M, Straub A, Gimmi U, Salzmann D (2010) The recent landscape history of Limpach Valley, Switzerland: Considering three empirical hypotheses on driving forces of landscape change. Landsc Ecol 25:287-297

Burkhard B, Kroll F, Nedkov S, Müller F (2012) Mapping ecosystem service supply, demand and budgets. Ecol Ind 21:17-29

Carpenter SR, Bennett EM, Peterson GD (2006) Scenarios for ecosystem services: an overview. Ecol Soc 11(1):29

Carreño L, Frank FC, Viglizzo EF (2012) Tradeoffs between economic and ecosystem services in Argentina during 50 years of land-use change. Agric Ecosyst Environ 154:68-77

Chen Y, Jessel B, Fu B, Yu X, Pittock J (2013) Ecosystem services and management strategy in China. Springer, Dordrecht

de Groot RS, Wilson M, Boumans R (2002) A typology for the description, classification and valuation ecosystem functions, goods and services. Ecol Econ 41:393-408

Forman RTT, Russell EWB (1983) Evaluation of historical data in ecology. Bull Ecol Soc Am 64:5-7

Forsius M, Anttila S, Arvola L, Bergstrom I, Hakola H, Heikkinen HI, Jelenius J, Hyvarinen M, Jylha K, Karjalainen J, Kaskinen T, Laine K, Nikinmaa E, Letonen-Sainio P, Rankinen K, Reinikainen M, Setala H, Vuorenmaa J (2013) Impacts and adaptation options of climate change on ecosystem services in Finland: a model based study. Curr Opin Environ Sustain 5:26-40

Geneletti D (2013) Ecosystem services in environmental impact assessment and strategic environmental assessment. Environ Impact Assess Rev 40:1-2

Gómez-Baggethun E, Mingorria S, Reyes-Garcia V, Valvet L, Montes C (2010) The history of ecosystem services in economic theory and practice: From early notions to markets and payment schemes. Ecol Econ 69:1209-1218

Grêt-Regamey A, Brunner SH, Kienast F (2012) Mountain ecosystem services: who cares? Mountain Res Dev 32(S1):S23-S34

Grêt-Regamey A, Rabe SE, Crespo R, Lautenbach S, Ryffel A, Schlup B (2014) On the importance of non-linear relationships between landscape patterns and the sustainable provision of ecosystem services. Landsc Ecol 29:201-212

Haines-Young R, Potschin M (2009) The links between biodiversity, ecosystem services and human well-being. In: Raffaelli D, Frid C (eds) Ecosystem ecology: a new synthesis. BES ecological reviews series, CUP, Cambridge

Hammett JE (1992) The shapes of adaptation-historical ecology of anthropogenic landscapes in the southeastern United States. Landsc Ecol 7:121-135 
Helfenstein J, Kienast F (2014) Ecosystem service state and trends at the regional to national level: a rapid assessment. Ecol Ind 36:11-18

Iverson L, Echeverria C, Nahuelhual L, Luque S (2014) Ecosystem services in changing landscapes: An introduction. Landsc Ecol 29:181-186

Jiang M, Bullok JM, Hooftman DAP (2013) Mapping ecosystem service and biodiversity changes over 70 years in a rural English county. J Appl Ecol 50:841-850

Jones KB, Zurlini G, Kienast F, Petrosillo I, Edwards T, Wade TG, Li B, Zaccarelli N (2013) Informing landscape planning and design for sustaining ecosystem services from existing spatial patterns and knowledge. Landsc Ecol 28:1175-1192

Kienast F, Wildi O, Ghosh S (2007) A changing world. Challenges for landscape research, vol 8., Landscape SeriesSpringer, Dordrecht

Kienast F, Bolliger J, Potschin M, de Groot R, Verburg PH, Heller I, Wascher D, Haines-Young R (2009) Assessing landscape functions with broad-scale environmental data: insights gained from a prototype development for Europe. Environ Manage 44:1099-1120

Koschke L, Furst C, Frank S, Makeschin F (2012) A multicriteria approach for an integrated land-cover-based assessment of ecosystem services provision to support landscape planning. Ecol Ind 21:54-66

Lauber S, Herzog F, Seidl I, Böni R, Bürgi M, Gmür P, Hofer G, Mann S, Raaflaub M, Schick M, Schneider M, Wunderli R (eds.) (2013) Zukunft der Schweizer Alpwirtschaft: Fakten, Analysen und Denkanstösse aus dem Forschungsprogramm AlpFUTUR. Birmensdorf, Eidg. Forschungsanstalt für Wald, Schnee und Landschaft WSL; Zürich-Reckenholz, Forschungsanstalt Agroscope

Lautenbach S, Kugel C, Lausch A, Seppelt R (2011) Analysis of historical changes in regional ecosystem service provisioning using land use data. Ecol Ind 11:676-687

Layke C, Mapendembe A, Brown C, Walpole M, Winn J (2012) Indicators from the global and sub-global millennium ecosystem assessments: An analysis and next steps. Ecol Ind 17:77-87

Long HL, Tang GP, Li XB, Heilig GK (2007) Socio-economic driving forces of land-use change in Kunshan, the Yangtze River Delta economic area of China. J Environ Manage 83:351-364

Mahmoud M, Liu YQ, Hartmann H, Stewart S, Wagener T, Semmens D, Stewart R, Gupta H, Dominguez D, Dominguez F, Hulse D, Letcher R, Rashleigh B, Smith C, Street R, Ticehurst J, Twery M, van Delden H, Waldick R, White D, Winter L (2009) A formal framework for scenario development in support of environmental decision-making. Environ Model Softw 24(7):798-808

Millennium Ecosystem Assessment (2005) Ecosystems and human well-being: synthesis. Island Press, Washington, DC

Morán-Ordóñez A, Bugter R, Suárez-Seoane S, de Luis E, Calvo L (2013) Temporal changes in socio-ecological systems and their impact on ecosystem services at different governance scales: a case study of heathlands. Ecosystems 16:765-782

Nahuelhual L, Carmona A, Aguayo M, Echeverria C (2014) Land use change and ecosystem services provision: a case study of recreation and ecotourism opportunities in southern Chile. Landsc Ecol 29:329-344

Nassauer J, Corry R, Cruse RM (2007) Alternative Scenarios for Future Iowa Agricultural Landscapes. In: Nassauer J, Santelmann M, Scavia D (eds) From the corn belt to the Gulf: societal and environmental implications of alternative agricultural futures. Resources for the Future Press, Washington DC

Nixon K, Silbernagel J, Price J, Miller N, Swaty R (2014) Habitat availability for multiple avian species under modeled alternative conservation strategies for the Two Hearted River Watershed in Michigan's Upper Peninsula, USA. J Nat Conserv. doi:10.1016/j.jnc.2014.02.005

Norgaard RB (2010) Ecosystem services: From eye-opening metaphor to complexity blinder. Ecol Econ 69:1219-1227

Olsson EGA, Austrheim G, Grenne SN (2000) Landscape change patterns in mountains, land use and environmental diversity, Mid-Norway 1960-1993. Landsc Ecol 15:155-170

Peterson GD, Cumming GS, Carpenter SR (2003) Scenario planning: a tool for conservation in an uncertain world. Conserv Biol 17(2):358-366

Pfister C (ed) (1994) Das 1950er Syndrom. Der Weg in die Konsumgesellschaft. Bern, Haupt

Price J, Silbernagel J, Miller N, Swaty R, White M, Nixon K (2012) Eliciting expert knowledge to inform landscape modeling of conservation scenarios. Ecol Mod 229:76-87

Santelmann M, Freemark K, Sifneos J, White D (2006) Assessing effects of alternative agricultural practices on wildlife habitat in Iowa, USA. Agric Ecosyst Environ 113(1-4):243-253

Schröter D, Cramer W, Leemans R, Prentice IC, Araújo MB, Arnell NW, Bondeau A, Bugmann H, Carter TR, Gracia CA, de la Vega-Leinert AC, Erhard M, Ewert F, Glendining M, House JI, Kankaanpää S, Klein RJT, Lavorel S, Lindner M, Metzger MJ, Meyer J, Mitchell TD, Reginster I, Rounsevell M, Sabaté S, Sitch S, Smith B, Smith J, Smith P, Sykes MT, Thonicke K, Thuiller W, Tuck G, Zaehle S, Zierl B (2005) Ecosystem service supply and vulnerability to global change in Europe. Science 310:1333-1337

Schröter M, Zanden EH, Oudenhoven AP, Remme RP, SernaChavez HM, Groot RS, Opdam P (2014) Ecosystem services as a contested concept: a synthesis of critique and counter-arguments. Conserv Lett (online first)

Silbernagel J, Martin SR, Gale MR, Chen J (1997) Prehistoric, historic, and present settlement patterns related to ecological hierarchy in the Eastern Upper Peninsula of Michigan, U.S.A. Landsc Ecol 12:223-240

Silbernagel J, Price J, Swaty R, Miller N (2011) The next frontier: assessing forest conservation strategy effectiveness. In: Li C, Lafortezza R, Chen J (eds) Landscape ecology and forest management: challenges and solutions in a changing globe. Springer, Berlin

Strüby A (1914) Die Alp- und Weidewirtschaft in der Schweiz. Schweizerische Alpstatistik, Schlussband. Solothurn, Vogt-Schild

Swearingen A, Silbernagel J, Price J, Swaty R, Miller N, Nixon $\mathrm{K}$ (in press) Modeling management and climate disturbances to evaluate landscape scale conservation efficacy. In press for Proceedings of ST-SM Conference, September

Thayer R (2008) The world shrinks, the world expands: Information, energy, and relocalization. Landsc J 27(1):9-22 
Tilman D, Socolow R, Foley JA, Hill J, Larson E, Lynd L, Pacala S, Reilly J, Searchinger T, Somerville C, Williams R (2009) Beneficial biofuels - the food, energy, and environment trilemma. Science 325:270f

Wallace KJ (2007) Classification of ecosystem services: problems and solution. Biol Conserv 139:235-246

Werthemann A, Imboden A (1982) Die Alp- und Weidewirtschaft in der Schweiz: Zusammenfassung der Alpkatastererhebungen. Bern, BLW

Wilhere GF, Linders MJ, Cosentino BL (2007) Defining alternative futures and projecting their effects on the spatial distribution of wildlife habitats. Landsc Urban Plan 79(3-4):385-400

Wilkinson C, Saarne T, Peterson GD, Colding J (2013) Strategic spatial planning and the ecosystem services concept-an historical exploration. Ecol Soc 18:37

Wu J (2013) Landscape sustainability science: ecosystem services and human well-being in changing landscapes. Landsc Ecol 28:999-1023 